\title{
Knowledge and Practice of Personal Protective Equipment among Students of Different Healthcare Specialties during COVID-19 Pandemic
}

SIRAJ DAA KHAN ${ }^{1}$, MUSLEH AL-GARNI², ABDULLRAHMAN SAEED HADI ALALHARITH ${ }^{3}$, MOHAMMAD DAFER ALALHARITH ${ }^{4}$, OBAID SALEH OBAID 5 , SALEH SAEED AL BAALTAHIN ${ }^{6}$, MOHAMMAD ABDULKAREEM ALNAJI ${ }^{7}$

$(\mathrm{cc})$ EY-NC-ND

\section{ABSTRACT}

Introduction: Healthcare professionals who are constantly working to treat the patients of Coronavirus Disease-2019 (COVID-19) are at great risk. So the only method they can prevent themselves while working is the use of Personal Protective Equipment (PPE). The use of PPE has increased with the spread of Severe Acute Respiratory Syndrome Coronavirus-2 (SARS-CoV-2).

Aim: To evaluate the knowledge and practice of students of different healthcare specialties regarding the use of PPE.

Materials and Methods: The present cross-sectional study was conducted from October 2020 to December 2020 on healthcare students of different healthcare specialties of Najran University, Saudi Arabia. Participants were asked questions about the practice and knowledge of PPE via an electronic link of a questionnaire. Collected data were statistically analysed for frequency and association of responses by using Statistical Package for the Social Sciences (SPSS) version 23.0.

Results: Total of 606 students (females were 122, males were 484) from different health specialities i.e., Medical $(25.4 \%)$,
Dental (42.1\%), Pharmacy (11.2\%), Nursing (13.4\%) and Physiotherapy $(7.9 \%)$ participated in this survey. Most of the participants ( 110 from the medical field, 142 from dental, 42 from pharmacy and 63 from nursing and 28 from physiotherapy) were familiar with the word PPE before this pandemic. There was a significant relationship ( $p$-value $<0.0001$ ) between the specialty and practice of PPE. The majority of the participants $(52 \%)$ did not know the Occupational Safety and Health Administration (OSHA) guideline and $55.9 \%$ were not aware of donning and doffing. Only $44.7 \%$ of professionals used N95 before the pandemic and $41.9 \%$ did not use N95 before COVID-19. While using the N95 mask $58.2 \%$ felt comfortable and $11.4 \%$ didn't feel comfortable and the remaining participants were not sure.

Conclusion: Although most participants practiced and had knowledge about the use and handling of PPE, but still there is a need to improve their knowledge and train them about its importance during COVID-19. Their knowledge can be improved by different training programs and health education.

Keywords: Coronavirus disease-2019, Gown, Healthcare speciality, N95 mask, Pandemic

\section{INTRODUCTION}

A lower respiratory tract infection emerged in 2019 in Wuhan city. Later on, it was concluded that it is due to a virus called Severe Acute Respiratory Syndrome Coronavirus-2 (SARS-CoV-2). In February 2020, World Health Organisation (WHO) declared a pandemic situation throughout the world and named this disease Coronavirus Disease-2019 (COVID-19) [1,2] direct contact or droplets are the modes of transmission. So, the isolation is the only method to control this epidemic $[1,3]$. Health professionals who are constantly working to treat the patients of COVID-19 are at great risk. So, the only method they can prevent themselves while working is the use of PPE [4,5]. Another precaution is to stay $2 \mathrm{~m}$ away from the patients even while using gloves, face masks and aprons are essential for fluid resistance. Eye protection is also necessary when working within $2 \mathrm{~m}$ with patients. When there is a high risk, airborne precautions are important to avoid droplets. Gowns having long sleeves, N95 mask, face shield and purifying respirators are included in the Personal Protective Equipment (PPE) kit used for airborne precaution $[4,6]$.

It has been reported that fear of getting the infection and working in PPE for hours lead to stress which ultimately affects health workers defence system negatively [7,8]. Also, the use of N95 mask, face shield, surgical, Filtering Face Piece 2 (FFP2) and Filtering Face Piece 3 (FFP3), glove and goggles caused skin problems in health workers $[7,9,10]$. In the study of $\mathrm{Hu} \mathrm{K}$ et al.,
$27.9 \%$ experienced face itching and $68.9 \%$ of workers faced nasal bridge injury with the use of N95 mask during the COVID-19 pandemic [9]. In addition to these problems, healthcare workers faced other problems like breathing discomfort, fogging in face shield and goggles, sweating, problems in basic needs i.e., excretion and nutrition $[10,11]$. Therefore, training documents are being developed by organisations to protect the workers from PPE associated problems $[7,12]$

The practice and handling of PPE's should be appropriate, a study about knowledge and practice of PPE was never conducted on healthcare students of Najran university, therefore the primary aim of the study was to assess the knowledge about the use of PPE and correct practice of health workers during their routine.

\section{MATERIALS AND METHODS}

This questionnaire based cross-sectional study was conducted among students of Najran University healthcare specialties, Saudi Arabia from October 2020 to December 2020. Ethical approval was taken from Scientific Research Ethical Committee (Reference No.:442-40-38958-DS). The study was conducted by the simple random sampling method and 606 students from different fields i.e., medical, dental, nursing, pharmacy and physiotherapy participated in this survey. The aim of the survey was explained to participants. Inclusion criteria: Only students studying full time and working on patients were included in the study. 
Exclusion criteria: The students not working on the patients and studying part-time were excluded from the study.

\section{Questionnaire}

[Annexure-1] was developed with the suggestions of experienced professionals (according to guidelines given by WHO for infection control and Rational use of PPE for COVID-19 [3] in health fields and validated (Kappa=0.78) by a pilot study in a small group of dental students. It had three main parts.

- $\quad$ The first part was the demographic questions (4 questions).

- Second part contained the questions about the practice of PPE (7 questions) and

- $\quad$ The third part was about knowledge of PPE (12 questions).

The web link of the questionnaire was distributed among students electronically. Two months were given to students to fill the questionnaire and weekly reminder were sent using university email and WhatsApp application.

\section{STATISTICAL ANALYSIS}

Descriptive statistics in terms of frequency and association were used to analyse the compiled data and for association Chi-square test was used with Statistical Package for the Social Sciences (SPSS) version 23.0. A p-value $<0.05$ considered statistically significant.

\section{RESULTS}

Total 606 students from different health specialities i.e., Medical (25.4\%), Dental (42.1\%), Pharmacy (11.2\%), Nursing (13.4\%) and Physiotherapy (7.9\%) participated in this survey. Out of total, 122 (20.1\%) were female and 484 (79.9\%) were male. According to their qualification, 293 were undergraduate students, 241 were interns and 72 were postgraduate students. They were grouped according to their working hours as 291 professionals worked for 1-3 hours, 237 worked for 4-6 hours and 78 participants worked for more than 6 hours [Table/Fig-1].

Most of the participants (110 from the medical field, 142 from dental, 42 from pharmacy and 63 from nursing and 28 from physiotherapy) were familiar with the word PPE before this pandemic. Only 392 (64.7\%) participants used the PPE before COVID-19. During the pandemic $376(62.0 \%)$ health workers always used PPE and 57 (9.4\%) practiced it sometimes while 173 (28.5\%) didn't use PPE even during COVID-19. Among 433 participants who practiced PPE, 345 said that they change their PPE after every patient. Most of the participants 268 (61.9\%) thought that PPE cannot be reused. Out of 433, 216 participants

\begin{tabular}{|c|c|c|}
\hline Variables & Number (n) & Percentage \\
\hline \multicolumn{3}{|l|}{ Gender } \\
\hline Female & 122 & 20.1 \\
\hline Male & 484 & 79.9 \\
\hline \multicolumn{3}{|l|}{ Speciality } \\
\hline Medical & 154 & 25.4 \\
\hline Dental & 255 & 42.1 \\
\hline Pharmacy & 68 & 11.2 \\
\hline Nursing & 81 & 13.4 \\
\hline Physiotherapy & 48 & 7.9 \\
\hline \multicolumn{3}{|l|}{ Qualification } \\
\hline Undergraduate student & 293 & 48.3 \\
\hline Interns & 241 & 39.8 \\
\hline Postgraduate student & 72 & 11.9 \\
\hline \multicolumn{3}{|l|}{ Working hours } \\
\hline 1-3 hours & 291 & 48.0 \\
\hline 4-6 hours & 237 & 39.1 \\
\hline More than 6 hours & 78 & 12.9 \\
\hline Total & 606 & 100.0 \\
\hline
\end{tabular}

always faced difficulties or experienced incidents while using PPE and 61 experienced sometimes. There was a significant relation relationship ( $p$-value $<0.0001$ ) between the specialty and practice of PPE [Table/Fig-2]. Mouth mask was the most commonly used PPE followed by gloves and medical gown. Medical shoe cover was the least used PPE by participants [Table/Fig-3].

The majority of the participants (52\%) did not know the Occupational Safety and Health Administration (OSHA) guideline and 55.9\% were not aware of donning and doffing. Only 220 participants out of 606 knew OSHA guidelines and only 179 professionals knew donning and doffing. Only 238 health workers said that their preferred gown type was woven. However, non woven gown was chosen by 193 participants. Only 248 professionals agreed that during a pandemic best protective gown was a laminated gown while 174 said it was non laminated. The number of participants who chose $\mathrm{N} 95$ as the best mask during COVID-19 was 388 (64.0\%), 169 (27.9\%) said N95 with respirator while the remaining participant (8.1) agreed on the respirator. Only $44.7 \%$ of professionals used N95 before the pandemic and 41.9\% did not use N95 before COVID-19. The relationship between specialty

\begin{tabular}{|c|c|c|c|c|c|c|c|c|c|}
\hline \multirow[b]{2}{*}{ Questions } & \multirow[b]{2}{*}{ Response } & \multicolumn{5}{|c|}{ Speciality } & \multirow[b]{2}{*}{ Total } & \multirow[b]{2}{*}{ Chi-square } & \multirow[b]{2}{*}{$p$-value } \\
\hline & & Medical & Dental & Pharmacy & Nursing & Physiotherapy & & & \\
\hline \multirow{3}{*}{$\begin{array}{l}\text { Did you know the word } \\
\text { PPE before COVID-19 } \\
\text { Pandemic? }\end{array}$} & Yes & $110(18.2 \%)$ & $142(23.4 \%)$ & 42 (6.9\%) & 63 (10.4\%) & $28(4.6 \%)$ & 385 (63.5\%) & \multirow{3}{*}{48.793} & \multirow{3}{*}{0.0001} \\
\hline & No & 26 (4.3\%) & 107 (17.7\%) & 22 (3.6\%) & 14 (2.3\%) & $14(2.3 \%)$ & $183(30.2 \%)$ & & \\
\hline & I don't know & $18(3.0 \%)$ & $6(1.0 \%)$ & $4(0.7 \%)$ & $4(0.7 \%)$ & $6(1.0 \%)$ & 38 (6.3\%) & & \\
\hline \multirow{3}{*}{$\begin{array}{l}\text { Did you use PPE before } \\
\text { COVID-19 pandemic? }\end{array}$} & Yes & 114 (18.8\%) & $146(24.1 \%)$ & 37 (6.1\%) & 66 (10.9\%) & $29(4.8 \%)$ & 392 (64.7\%) & \multirow{3}{*}{58.388} & \multirow{3}{*}{0.0001} \\
\hline & No & $28(4.6 \%)$ & $106(17.5 \%)$ & $29(4.8 \%)$ & $12(2.0 \%)$ & $12(2.0 \%)$ & 187 (30.9\%) & & \\
\hline & I don't know & $12(2.0 \%)$ & $3(0.5 \%)$ & $2(0.3 \%)$ & $3(0.5 \%)$ & $7(1.2 \%)$ & $27(4.5 \%)$ & & \\
\hline \multirow{3}{*}{$\begin{array}{l}\text { Do you use PPE during } \\
\text { COVID- } 19 \text { pandemic? }\end{array}$} & Always & $112(18.5 \%)$ & $143(23.6 \%)$ & 36 (5.9\%) & $51(8.4 \%)$ & $34(5.6 \%)$ & $376(62.0 \%)$ & \multirow{3}{*}{70.445} & \multirow{3}{*}{0.0001} \\
\hline & Never & 21 (3.5\%) & $108(17.8 \%)$ & 19 (3.1\%) & $16(2.6 \%)$ & $9(1.5 \%)$ & $173(28.5 \%)$ & & \\
\hline & Sometimes & 21 (3.5\%) & $4(0.7 \%)$ & $13(2.1 \%)$ & 14 (2.3\%) & $5(0.8 \%)$ & 57 (9.4\%) & & \\
\hline \multirow{3}{*}{$\begin{array}{l}\text { Do you change PPE } \\
\text { after every patients? }\end{array}$} & Always & 100 (23.1\%) & 131 (30.3\%) & $32(7.4 \%)$ & 52 (12.0\%) & 30 (6.9\%) & 345 (79.7\%) & \multirow{3}{*}{18.845} & \multirow{3}{*}{0.016} \\
\hline & Never & 10 (2.3\%) & $9(2.1 \%)$ & $7(1.6 \%)$ & $4(0.9 \%)$ & $3(0.7 \%)$ & $33(7.6 \%)$ & & \\
\hline & Sometimes & $23(5.3 \%)$ & $7(1.6 \%)$ & $10(2.3 \%)$ & $9(2.1 \%)$ & $6(1.4 \%)$ & $55(12.7 \%)$ & & \\
\hline \multirow{3}{*}{ Can PPE be reused? } & Yes & 46 (10.6\%) & $22(5.1 \%)$ & $18(4.2 \%)$ & 19 (4.4\%) & $7(1.6 \%)$ & $112(25.9 \%)$ & \multirow{3}{*}{59.570} & \multirow{3}{*}{0.0001} \\
\hline & No & 59 (13.6\%) & $122(28.2 \%)$ & 25 (5.8\%) & $40(9.2 \%)$ & $22(5.1 \%)$ & 268 (61.9\%) & & \\
\hline & I don't know & $28(6.5 \%)$ & $3(0.7 \%)$ & $6(1.4 \%)$ & $6(1.4 \%)$ & $10(2.3 \%)$ & $53(12.2 \%)$ & & \\
\hline
\end{tabular}




\begin{tabular}{|c|c|c|c|c|c|c|c|c|c|}
\hline \multirow{3}{*}{$\begin{array}{l}\text { Experienced difficulties, } \\
\text { incidents or accidents } \\
\text { while using PPE? }\end{array}$} & Always & 66 (15.2\%) & $93(21.5 \%)$ & 16 (3.7\%) & 25 (5.8\%) & 16 (3.7\%) & 216 (49.9\%) & \multirow{3}{*}{35.622} & \multirow{3}{*}{$<0.0001$} \\
\hline & Never & 38 (8.8\%) & 41 (9.5\%) & 24 (5.5\%) & $32(7.4 \%)$ & $21(4.8 \%)$ & 156 (36.0\%) & & \\
\hline & Sometimes & 29 (6.7\%) & 13 (3.0\%) & 9 (2.1\%) & $8(1.8 \%)$ & 2 (0.5\%) & 61 (14.1\%) & & \\
\hline
\end{tabular}

[Table/Fig-2]: Association between speciality and practice of Personal Protective Equipment (PPE).

$p$-value $<0.05$ was considered statistically significant.

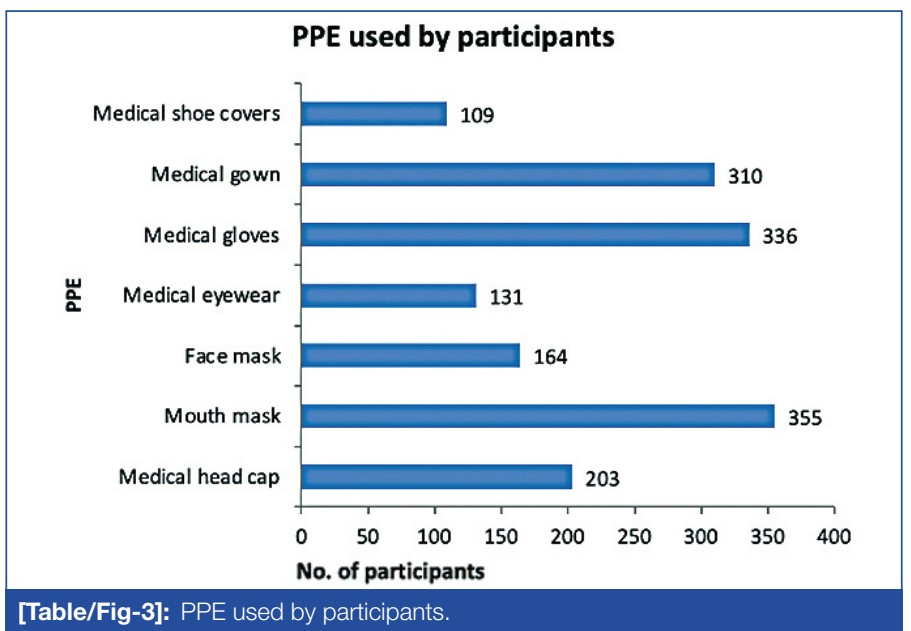

and different questions about knowledge of PPE was significant (p-value <0.0001) [Table/Fig-4a].

While using the N95 mask 58.2\% felt comfortable and $11.4 \%$ did not feel comfortable and the remaining participants were not sure. Only 260 participants used face shields before the pandemic. Only 227 (37.5\%) used eye protection before this pandemic situation. Among 227 participants who protected their eyes, safety glasses were used by 191 (84.1\%), visors by 24 (10.6\%) and personal glasses by 12 (5.3\%) as eye protection. About blurring of an image while using eye protection 181 (79.7\%) participants agreed. Only 289 specialists thought that it is important to educate the health students about PPE and 157 didn't consider it important. All the questions except about type of eye protection ( $p$-value $=0.990)$ and altered vision ( $p$-value $=0.112)$ showed significant relation $(p<0.0001)$ between knowledge of PPE and specialty [Table/Fig-4b].

\begin{tabular}{|c|c|c|c|c|c|c|c|c|c|}
\hline \multirow[b]{2}{*}{ Questions } & \multirow[b]{2}{*}{ Response } & \multicolumn{5}{|c|}{ Speciality } & \multirow[b]{2}{*}{ Total } & \multirow{2}{*}{$\begin{array}{l}\text { Chi- } \\
\text { square }\end{array}$} & \multirow[b]{2}{*}{$p$-value } \\
\hline & & Medical & Dental & Pharmacy & Nursing & Physiotherapy & & & \\
\hline \multirow{3}{*}{$\begin{array}{l}\text { Know the OSHA guideline } \\
\text { for PPE? }\end{array}$} & Yes & $61(10.1 \%)$ & $63(10.4 \%)$ & 27 (4.5\%) & $49(8.1 \%)$ & $20(3.3 \%)$ & $220(36.3 \%)$ & \multirow{3}{*}{77.948} & \multirow{3}{*}{0.0001} \\
\hline & No & $60(9.9 \%)$ & $178(29.4 \%)$ & $33(5.4 \%)$ & $26(4.3 \%)$ & $18(3.0 \%)$ & $315(52.0 \%)$ & & \\
\hline & I don't know & $33(5.4 \%)$ & $14(2.3 \%)$ & $8(1.3 \%)$ & $6(1.0 \%)$ & $10(1.7 \%)$ & $71(11.7 \%)$ & & \\
\hline \multirow{3}{*}{$\begin{array}{l}\text { Know the word Donning and } \\
\text { Doffing? }\end{array}$} & Yes & $62(10.2 \%)$ & $42(6.9 \%)$ & 20 (3.3\%) & $37(6.1 \%)$ & $18(3.0 \%)$ & 179 (29.5\%) & \multirow{3}{*}{72.155} & \multirow{3}{*}{0.0001} \\
\hline & No & $60(9.9 \%)$ & $191(31.5 \%)$ & 38 (6.3\%) & $30(5.0 \%)$ & $20(3.3 \%)$ & 339 (55.9\%) & & \\
\hline & I don't know & $32(5.3 \%)$ & $22(3.6 \%)$ & $10(1.7 \%)$ & $14(2.3 \%)$ & $10(1.7 \%)$ & $88(14.5 \%)$ & & \\
\hline \multirow{3}{*}{ Protective gown you prefer? } & Woven & $75(12.4 \%)$ & 89 (14.7\%) & $21(3.5 \%)$ & $35(5.8 \%)$ & $18(3.0 \%)$ & $238(39.3 \%)$ & \multirow{3}{*}{57.003} & \multirow{3}{*}{0.0001} \\
\hline & Non woven & $26(4.3 \%)$ & 117 (19.3\%) & $26(4.3 \%)$ & $15(2.5 \%)$ & $9(1.5 \%)$ & $193(31.8 \%)$ & & \\
\hline & I don't know & $53(8.7 \%)$ & $49(8.1 \%)$ & $21(3.5 \%)$ & $31(5.1 \%)$ & $21(3.5 \%)$ & $175(28.9 \%)$ & & \\
\hline \multirow{3}{*}{$\begin{array}{l}\text { Which Protective Gown is } \\
\text { best to protect from COVID- } \\
19 \text { Infection? }\end{array}$} & Laminated & $77(12.7 \%)$ & $95(15.7 \%)$ & $25(4.1 \%)$ & $36(5.9 \%)$ & 15 (2.5\%) & 248 (40.9\%) & \multirow{3}{*}{60.932} & \multirow{3}{*}{0.0001} \\
\hline & Non laminated & $21(3.5 \%)$ & 111 (18.3\%) & 17 (2.8\%) & 14 (2.3\%) & $11(1.8 \%)$ & 174 (28.7\%) & & \\
\hline & I don't know & $56(9.2 \%)$ & 49 (8.1\%) & 26 (4.3\%) & $31(5.1 \%)$ & 22 (3.6\%) & $184(30.4 \%)$ & & \\
\hline \multirow{3}{*}{$\begin{array}{l}\text { Which mask is better during } \\
\text { COVID-19? }\end{array}$} & N95 & 118 (19.5\%) & 146 (24.1\%) & 40 (6.6\%) & $54(8.9 \%)$ & 30 (5.0\%) & $388(64.0 \%)$ & \multirow{3}{*}{34.458} & \multirow{3}{*}{0.0001} \\
\hline & N95 with respirator & $23(3.8 \%)$ & 96 (15.8\%) & 22 (3.6\%) & $18(3.0 \%)$ & $10(1.7 \%)$ & 169 (27.9\%) & & \\
\hline & Respirator & $13(2.1 \%)$ & $13(2.1 \%)$ & $6(1.0 \%)$ & $9(1.5 \%)$ & $8(1.3 \%)$ & $49(8.1 \%)$ & & \\
\hline \multirow{3}{*}{$\begin{array}{l}\text { Have you used N95 mask } \\
\text { before COVID-19 pandemic? }\end{array}$} & Yes & $79(13.0 \%)$ & $104(17.2 \%)$ & 22 (3.6\%) & $46(7.6 \%)$ & $20(3.3 \%)$ & $271(44.7 \%)$ & \multirow{3}{*}{47.880} & \multirow{3}{*}{0.0001} \\
\hline & No & $41(6.8 \%)$ & $132(21.8 \%)$ & 39 (6.4\%) & $25(4.1 \%)$ & $17(2.8 \%)$ & 254 (41.9\%) & & \\
\hline & I don't know & $34(5.6 \%)$ & 19 (3.1\%) & $7(1.2 \%)$ & $10(1.7 \%)$ & $11(1.8 \%)$ & $81(13.4 \%)$ & & \\
\hline
\end{tabular}

[Table/Fig-4]: (a): Association between speciality and knowledge about PPE.

OSHA: Occupational safety and health administration; $\mathrm{p}$-value $<0.05$ was considered statistically significant

\begin{tabular}{|c|c|c|c|c|c|c|c|c|c|}
\hline \multirow[b]{2}{*}{ Question } & \multirow[b]{2}{*}{ Response } & \multicolumn{5}{|c|}{ Speciality } & \multirow[b]{2}{*}{ Total } & \multirow{2}{*}{$\begin{array}{l}\text { Chi- } \\
\text { square }\end{array}$} & \multirow[b]{2}{*}{$p$-value } \\
\hline & & Medical & Dental & Pharmacy & Nursing & Physiotherapy & & & \\
\hline \multirow{3}{*}{$\begin{array}{l}\text { Do you feel comfortable } \\
\text { for breathing or talking } \\
\text { while wearing N95 } \\
\text { mask? }\end{array}$} & Yes & 58 (16.5\%) & 62 (17.6\%) & 25 (7.1\%) & 40 (11.4\%) & $20(5.7 \%)$ & $205(58.2 \%)$ & \multirow{3}{*}{43.275} & \multirow{3}{*}{0.0001} \\
\hline & No & 17 (4.8\%) & $7(2.0 \%)$ & $4(1.1 \%)$ & 11 (3.1\%) & $1(0.3 \%)$ & 40 (11.4\%) & & \\
\hline & I don't know & $38(10.8 \%)$ & 54 (15.3\%) & $0(0.0 \%)$ & $5(1.4 \%)$ & $10(2.8 \%)$ & 107 (30.4\%) & & \\
\hline \multirow{3}{*}{$\begin{array}{l}\text { Have you used face } \\
\text { shield before COVID-19? }\end{array}$} & Yes & 66 (10.9\%) & 82 (13.5\%) & 34 (5.6\%) & 54 (8.9\%) & 24 (4.0\%) & 260 (42.9\%) & \multirow{3}{*}{50.187} & \multirow{3}{*}{0.0001} \\
\hline & No & 37 (6.1\%) & $107(17.7 \%)$ & 27 (4.5\%) & $18(3.0 \%)$ & $12(2.0 \%)$ & 201 (33.2\%) & & \\
\hline & I don't know & $51(8.4 \%)$ & 66 (10.9\%) & $7(1.2 \%)$ & $9(1.5 \%)$ & $12(2.0 \%)$ & $145(23.9 \%)$ & & \\
\hline \multirow{3}{*}{$\begin{array}{l}\text { Did you use eye } \\
\text { protection before } \\
\text { COVID-19 pandemic? }\end{array}$} & Yes & 59 (9.7\%) & 75 (12.4\%) & 33 (5.4\%) & 43 (7.1\%) & 17 (2.8\%) & $227(37.5 \%)$ & \multirow{3}{*}{40.857} & \multirow{3}{*}{0.0001} \\
\hline & No & 49 (8.1\%) & $113(18.6 \%)$ & 30 (5.0\%) & 33 (5.4\%) & 15 (2.5\%) & $240(39.6 \%)$ & & \\
\hline & I don't know & 46 (7.6\%) & 67 (11.1\%) & $5(0.8 \%)$ & $5(0.8 \%)$ & $16(2.6 \%)$ & 139 (22.9\%) & & \\
\hline \multirow{3}{*}{$\begin{array}{l}\text { Which type of eye } \\
\text { protection you used? }\end{array}$} & Safety glasses & 51 (22.5\%) & 63 (27.8\%) & 28 (12.3\%) & 35 (15.4\%) & $14(6.2 \%)$ & $191(84.1 \%)$ & \multirow{3}{*}{1.638} & \multirow{3}{*}{0.990} \\
\hline & Visors & $5(2.2 \%)$ & $7(3.1 \%)$ & $4(1.8 \%)$ & $6(2.6 \%)$ & $2(0.9 \%)$ & 24 (10.6\%) & & \\
\hline & Personal glasses & $3(1.3 \%)$ & $5(2.2 \%)$ & $1(0.4 \%)$ & $2(0.9 \%)$ & $1(0.4 \%)$ & 12 (5.3\%) & & \\
\hline
\end{tabular}




\begin{tabular}{|c|c|c|c|c|c|c|c|c|c|}
\hline \multirow{3}{*}{$\begin{array}{l}\text { Does your vision altered } \\
\text { with eye protection? }\end{array}$} & Yes & 52 (22.9\%) & 58 (25.6\%) & 24 (10.6\%) & 33 (14.5\%) & $14(6.2 \%)$ & $181(79.7 \%)$ & \multirow{3}{*}{13.003} & \multirow{3}{*}{0.112} \\
\hline & No & $4(1.8 \%)$ & $14(6.2 \%)$ & $5(2.2 \%)$ & $10(4.4 \%)$ & $3(1.3 \%)$ & 36 (15.9\%) & & \\
\hline & I don't know & 3 (1.3\%) & 3 (1.3\%) & $4(1.8 \%)$ & 0 (0.0\%) & $0(0.0 \%)$ & $10(4.4 \%)$ & & \\
\hline \multirow{3}{*}{$\begin{array}{l}\text { It is important to educate } \\
\text { students of healthcare } \\
\text { specialties about PPE? }\end{array}$} & Yes & 79 (13.0\%) & 82 (13.5\%) & 38 (6.3\%) & $64(10.6 \%)$ & $26(4.3 \%)$ & $289(47.7 \%)$ & \multirow{3}{*}{76.546} & \multirow{3}{*}{0.0001} \\
\hline & No & $24(4.0 \%)$ & 88 (14.5\%) & $22(3.6 \%)$ & $13(2.1 \%)$ & $10(1.7 \%)$ & 157 (25.9\%) & & \\
\hline & I don't know & 51 (8.4\%) & 85 (14.0\%) & $8(1.3 \%)$ & $4(0.7 \%)$ & 12 (2.0\%) & $160(26.4 \%)$ & & \\
\hline
\end{tabular}

[Table/Fig-4]: (b): Association between speciality and knowledge about PPE (Question:19-24

$\mathrm{p}$-value $<0.05$ was considered statistically significant

\section{DISCUSSION}

With the spread of COVID-19, the use of PPE became important and essential especially for health workers who are in direct contact with the patients. To assess the knowledge and practice of students from different health-related fields, this survey was conducted. The number of individuals who practiced PPE before and during COVID-19 was almost the same. It has been reported that the use of PPE i.e., gloves, face shields and masks, caps, goggles, boot covers and protective clothing though cannot eliminate the risk but can reduce the chances of infection transmission [13]. In the present study, a mouth mask was the most commonly used PPE followed by gloves and gowns which is in accordance with the study of Turkish dentists and Canadian dentists [14,15]. A similar study done by Abukhelaif AEE, on nursing staff in Al-Baha, Saudi Arabia, observed gloves was the most effective mean for infection control [16].

Along with the use of PPE, WHO also suggested some preventive and mitigation measures as under [3]:

- $\quad$ Performing hand hygiene frequently with an alcohol-based hand rub if your hands are not visibly dirty or with soap and water if hands are dirty;

- $\quad$ Avoiding touching your eyes, nose, and mouth;

- $\quad$ Practicing respiratory hygiene by coughing or sneezing into a bent elbow or tissue and then immediately disposing of the tissue;

- Wearing a medical mask if you have respiratory symptoms and performing hand hygiene after disposing of the mask;

- Maintaining social distance (minimum of 1 meter) from persons with respiratory symptoms.

In the present study, a large number of participants didn't know donning and doffing. In a similar study in India, $45.4 \%$ of students of health sciences knew donning and doffing in the right sequence [17]. A 388 (64.05\%) choose the N95 mask as the best mask in the current survey. In another study, 85.5\% agreed that the face mask can prevent COVID-19 transmission [18].

In accordance with OSHA guidelines, 52\% of participants in this study were not aware of it. In the study of Kotian RP et al., 46.5\% got safety training for the use of PPE [19]. Although a remarkable number (almost half) of the participants responded correctly about knowledge of PPE, but a higher (67.8\%) positive response rate was observed in the study done by Ojha S et al., [20].

\section{Limitation(s)}

Since, it was a single center study the results cannot be generalised to the entire population.

\section{CONCLUSION(S)}

Although most participants practiced and had knowledge about the use and handling of PPE, but still there is a need to improve their knowledge and trained them about its importance during COVID19. Their knowledge can be improved by different training programs and health education. Besides that published guidance about PPE may improve the knowledge, confidence and awareness among healthcare specialists. It has been clear that if more body parts are covered with PPE, it provides better protection but at the same time, it is linked with the difficulty in donning and doffing PPE. Prolonged use of gown and gloves also increase the chances of infection, this risk can be reduced by educational interventions about practice and visual feedback on clothes and skin contamination at the time of PPE removal. Although, the results are appreciable but further studies are required for improvement about knowledge.

Authors contribution: SDK was the primary author, conceptualised the study, data cleaning and analysis, result interpretation, and drafting the manuscript. MAG helped in designing the study, development and validation of the questionnaire. ASA and MDA leaded to development and validation of the questionnaire. OSO, SSA-A and MAA leaded to development and validation of the questionnaire, data collection, communications with the participant.

\section{REFERENCES}

[1] Cascella M, Rajnik M, Aleem A, Dulebohn SC, Napoli RD. 2020. Features, Evaluation and Treatment Coronavirus (COVID-19) [Updated 2020 Apr 6]. In StatPearls. Treasure Island, FL: StatPearls Publishing. Retrieved from https:// www.ncbi.nlm.nih.gov/books/ NBK554776/.

[2] Park SE. Epidemiology, virology, and clinical features of severe acute respiratory syndrome-coronavirus-2 (SARS-CoV-2; Coronavirus Disease-19). Clin Exp Pediatr. 2020;63(4):119-24.

[3] World Health Organisation. Rational use of personal protective equipment for coronavirus disease (COVID-19): Interim guidance, 2020. World Health Organisation. Retrieved from https://apps.who.int/iris/handle/10665/331215. License: CC BY-NC-SA 3.0 IGO.

[4] Cook TM. Personal protective equipment during the COVID-19 pandemic a narrative review. Anaesthesia. 2020;75(7):920-27.

[5] Holland M, Zaloga DJ, Friderici CS. COVID-19 Personal Protective Equipment (PPE) for the emergency physician. Vis J Emerg Med. 2020;19:100740.

[6] World Health Organisation. Coronavirus disease 2019 (COVID-19): Situation report (p. 73). World Health Organisation. 2020. Retrieved from https://apps. who.int/ iris/handle/10665/331686

[7] Gefen A, Ousey K. Update to device-related pressure ulcers: SECURE prevention. COVID-19, face masks and skin damage. Journal of Wound Care. 2020;29(5):245-59.

[8] Yan Y, Chen H, Chen L, Cheng B, Diao P, Dong L, et al. Consensus of Chinese experts on protection of skin and mucous membrane barrier for healthcare workers fighting against coronavirus disease 2019. Dermatol Ther. 2020;e13310.

[9] Hu K, Fan J, Li X, Gou X, Li X, Zhou X. The adverse skin reactions of health care workers using personal protective equipment for COVID-19. Medicine. 2020;99:24.

[10] Jiang Q, Song S, Zhou J, Liu Y, Chen A, Bai Y, et al. The prevalence, characteristics, and prevention status of skin injury caused by personal protective equipment among medical staff in fighting COVID-19: A multicenter, cross-sectional study. Adv Wound Care (New Rochelle). 20209(7):357-64.

[11] Tabah A, Ramanan M, Laupland KB, Buetti N, Cortegiani A, Mellinghoff J, et al. Personal protective equipment and intensive care unit healthcareworker safety in the COVID-19 era (PPE-SAFE): An international survey. J Crit Care. 2020;59:70-75

[12] LeBlanc K, Heerschap C, Butt B, Bresnai-Harris J, Wiesenfeld L. Prevention and management of personal protective equipment skin injury: Update. NSWOCC; 2020

[13] Ran L, Chen X, Wang Y, Wu W, Zhang L, Tan X. Risk factors of healthcare workers with corona virus disease 2019: A retrospective cohort study in a designated hospital of Wuhan in China. Clin Infect Dis. 2020;71(16):2218-21.

[14] Yuzbasioglu E, Sarac D, Canbaz S, Sarac YS, Cengiz S. A survey of crossinfection control procedures: Knowledge and attitude of Turkish dentist. J Appl Oral Sci. 2009;17(6):565-69.

[15] McCarthy GM, MacDonald JK. The infection control practices of general dental practitioners. Infect Control Hosp Epidemiol. 1997;18:699-703.

[16] Abukhelaif AEE. Personal protective equipment knowledge and practices among nurses working at Al-Baha King Fahad Hospital, Saudi Arabia. J Healthc Commun. 2019;4(1):2 
[17] Modi PD, Nair G, Uppe A, Modi J, Tuppekar B, Gharpure AS, et al. COVID-19 awareness among healthcare students and professionals in Mumbai metropolitan region: A questionnaire-based survey. Cureus. 2020;12(4):e7514.

[18] Taghrir MH, Borazjani R, Shiraly R. COVID-19 and Iranian Medical Students; A survey on their related-knowledge, preventive behaviors and risk perception. Arch Iran Med. 2020;23(4):249-54.
[19] Kotian RP, Faujdar D, Kotian SP, D'souza B. Knowledge and understanding among medical imaging professionals in India during the rapid rise of the covid19 pandemic. Health Technol (Berl). 2020;10(6):1415-20.

[20] Ojha S, Debnath M, Sharma D, Niraula A. Knowledge of handling the personal protective equipment by frontline allied health professionals in COVID-19 outbreak a web-based survey study. J Radiol Nurs. 2021;40(2):01-05.

\section{PARTICULARS OF CONTRIBUTORS:}

1. Lecturer, Department of Preventive Dental Sciences, Faculty of Dentistry, Najran University, Najran, Saudi Arabia.

2. Lecturer, Department of Preventive Dental Sciences, Faculty of Dentistry, Najran University, Najran, Saudi Arabia.

3. Intern, Department of Preventive Dental Sciences, Faculty of Dentistry, Najran University, Najran, Saudi Arabia.

4. Intern, Department of Preventive Dental Sciences, Faculty of Dentistry, Nairan University, Nairan, Saudi Arabia.

5. Intern, Department of Preventive Dental Sciences, Faculty of Dentistry, Nairan University, Najran, Saudi Arabia.

6. Intern, Department of Preventive Dental Sciences, Faculty of Dentistry, Najran University, Najran, Saudi Arabia.

7. Intern, Department of Preventive Dental Sciences, Faculty of Dentistry, Najran University, Najran, Saudi Arabia.

NAME, ADDRESS, E-MAIL ID OF THE CORRESPONDING AUTHOR:

Siraj DAA Khan,

Lecturer, Faculty of Dentistry, Najran University, King Abdul Aziz Street,

Najran, Saudi Arabia.

E-mail: sdkhan@nu.edu.sa
PLAGIARISM CHECKING METHODS: Jain Het al.]

- Plagiarism X-checker: Jul 05, 2021

- Manual Googling: Oct 05, 2021

- iThenticate Software: Nov 23, 2021 (6\%)
ETYMOLOGY: Author Origin

Date of Submission: Jul 04, 2021

Date of Peer Review: Aug 18, 2021

Date of Acceptance: Oct 06, 2021

Date of Publishing: Dec 01, 2021

- Was Ethics Committee Approval obtained for this study? Yes

- For any images presented appropriate consent has been obtained from the subjects. NA

\section{ANNEXURE 1: QUESTIONNAIRE}

Knowledge and Practice of Personal Protective Equipment among Students of Najran University Healthcare Specialties during COVID19 Pandemic

${ }^{\star}$ Required

\section{AGREEMENT AND CONSENT *}

Check all that apply.

$\square$ Yes, I agree and give my consent to participate in the survey

A. DEMOGRAPHIC DATA OF THE PARTICIPANTS

2. Gender *

Mark only one oval.

$\square$ Female

$\square$ Male

3. Your Specialty *

Mark only one oval.

$\square$ Medical

$\square$ Dental

$\square$ Pharmacy

$\square$ Nursing

$\square$ Physiotherapy

4. Qualification *

Mark only one oval.

$\square$ Undergraduate Student

$\square$ Interns

$\square$ Postgraduate Student

5. Per day working hours with patients. *

Mark only one oval.

$\square$ 1-3 Hours

口 4-6 Hours

$\square$ More than 6 Hours

B. PRACTICE OF PPE

6. Did you know the word PPE before COVID-19 Pandemic? * Mark only one oval.

$\square$ Yes

$\square$ No

口 I don't know
7. While working on the patient, did you use PPE before COVID19 pandemic? *

Mark only one oval.

$\square$ Yes

$\square$ No

$\square$ Don't know

8. While working on the patient, do you use PPE during COVID19 pandemic? *

Mark only one oval.

$\square \quad$ Always Skip to question 9

$\square \quad$ Never Skip to question 14

$\square \quad$ Sometimes Skip to question 9

9. Which of the following PPE you use? *

Check all that apply.

$\square$ Medical head cap

$\square$ Mouth mask

$\square$ Face shield

$\square$ Medical eyewear

$\square$ Medical gloves

$\square$ Medical gown

$\square$ Medical shoe covers

10. Do you change PPE after every patients? *

Mark only one oval.

$\square$ Always

$\square$ Never

$\square$ Sometimes

11. Can PPE be reused? *

Mark only one oval.

$\square$ Yes

$\square$ No

口I don't know

12. Have you experienced difficulties, incidents or accidents while using PPE? *

Mark only one oval.

$\square \quad$ Always 
$\square \quad$ Never

$\square \quad$ Sometimes

C. KNOWLEDGE OF PPE

13. Do you know the OSHA guidelines about PPE? * Mark only one oval.

$\square$ Yes

$\square$ No

口 I don't know

14. Do you know the word Donning and Doffing? *

Mark only one oval.

$\square$ Yes

$\square$ No

口I don't know

15. Which protective gown you prefer to use? *

Mark only one oval.

$\square$ Woven

$\square$ Non woven

I don't know

16. Which Protective Gown you think best to protect from COVID19 Infection? *

Mark only one oval.

口 Laminated

$\square$ Non laminated

口 I don't know

17. While working on patient, which mask do you think is better during this COVID-19 pandemic? *

Mark only one oval.

$\square \mathrm{N95}$

$\square$ N95 with respirator

$\square$ Respirator

18 While working on patient, have you used N95 mask before COVID-19 pandemic? *

Mark only one oval.

$\quad$ Yes. Skip to question 19

№. Skip to question 20
- I don't know Skip to question 19

19. Do you feel comfortable for breathing or talking while wearing $\mathrm{N}-95$ mask? *

Mark only one oval.

$\square$ Yes

$\square$ No

口 I don't know

20. While working on patient, have you used medical face shield before COVID-19 pandemic? *

Mark only one oval.

$\square$ Yes

$\square$ No

口 l don't know

21. Did you use eye protection before COVID-19 pandemic? *

Mark only one oval.

$\square \quad$ Yes Skip to question 22

- No Skip to question 24

- I don't know Skip to question 24

22. Which type of eye protection you used? *

Mark only one oval.

$\square$ Safety Glasses

$\square$ Visors

$\square$ Personal Glasses

23. Does your vision altered with eye protection? *

Mark only one oval.

$\square$ Yes

$\square$ No

口I don't know

24. Do you believe it is important to educate students of healthcare specialties about PPE to prevent the spread of cross infection? * Mark only one oval.

$\square$ Yes

$\square$ No

口 l don't know 